FOLIA POMERANAE UNIVERSITATIS TECHNOLOGIAE STETINENSIS

Folia Pomer. Univ. Technol. Stetin., Oeconomica 2018, 344(91)2, 41-48

\title{
KONCEPCJA SPECJALNOŚCI DORADZTWO PODATKOWE I ZARZADZZANIE PODATKAMI NA KIERUNKU FINANSE I RACHUNKOWOŚĆ
}

\author{
THE CONCEPT OF TAX ADVISORY AND TAX MANAGEMENT SPECIALIZATION \\ IN FINANCE AND ACCOUNTING MAJOR
}

Katedra Rachunku Kosztów, Rachunkowości Zarządczej i Controllingu, Uniwersytet Ekonomiczny we Wrocławiu, ul. Komandorska 118/120, 54-345 Wrocław, e-mail: marcin.klinowski@ue.wroc.pl

\begin{abstract}
Summary. The aim of this study is to present and analyze the concept and content of teaching in the concept of tax advisory and tax management specialization. This specialization is offered to students of postgraduate studies in finance and accountancy major at the Faculty of Management, IT and Finance at Wrocław University of Economics. The general purpose of the specialization is to provide detailed knowledge and skills in the field of tax analysis, tax management, tax proceedings and inspection, analyses and tax decisions and business activity audit. Training within the specialization should be practical, closely linked to the requirements of the employers. It is also important that selection of appropriate pedagogical approaches can be crucial for the achievement of the intended specialization effects.
\end{abstract}

Słowa kluczowe: podatki, rachunkowość, koncepcja nauczania, metodyka zajęć.

Key words: taxes, accounting, teaching concept, methodology of lessons.

\section{WSTĘP}

Nieustannie zmieniający się rynek pracy wymusza na uczelniach wyższych wprowadzanie zmian w programach oraz sposobie kształcenia studentów. Jednym z podstawowych zadań uczelni wyższych jest bowiem przekazanie studentom odpowiedniej wiedzy i umiejętności, aby jako absolwenci z powodzeniem odnaleźli się na rynku pracy. Istotne jest również stwierdzenie, że metody nauczania też powinny być dostosowywane na bieżąco do aktualnych wymagań otoczenia.

Od uczelni ekonomicznych oczekuje się, aby między innymi umożliwiała studentom uzyskanie kompleksowych kompetencji w zakresie obciążeń publicznoprawnych. Dotyczy to w szczególności kierunku finanse i rachunkowość. Polskie uczelnie ekonomiczne w różnym zakresie realizują to założenie (Kuzior i Rówińska 2016). Tymczasem Uniwersytet Ekonomiczny we Wrocławiu w roku akademickim 2017/2018 uruchomił program, który umożliwia studentom wybór specjalności podatkowych w relacji komplementarnej zarówno na studiach pierwszego, jak i na studiach drugiego stopnia.

Studenci, którzy aktualnie dokonują wyboru specjalności na studiach drugiego stopnia, to głównie przedstawiciele pokolenia Z, czyli osób urodzonych po 1990 roku. Ich oczekiwania wobec pracy to dobrze płatna praca, dająca satysfakcję sama w sobie oraz umożliwiająca 
rozwijanie zainteresowań czy hobby (Biernacki 2016). Niewątpliwie specjalnościami, które umożliwiają spełnienie takich oczekiwań względem przyszłej pracy, są specjalności o charakterze doradczym.

Celem niniejszego opracowania jest prezentacja i analiza koncepcji oraz treści nauczania na specjalności doradztwo podatkowe i zarządzanie podatkami. Zaprezentowana postać specjalności jest efektem poszerzenia i udoskonalenia oferty kształcenia dla studentów w zakresie podatków na kierunku finanse i rachunkowość. To jednocześnie dopełnienie oferty przedmiotów podatkowych realizowanych z powodzeniem na kierunku od wielu lat.

\section{MATERIA I METODY}

Rozważania na temat koncepcji specjalności bazują na badaniu materiałów źródłowych z zakresu funkcjonowania specjalności doradztwo podatkowe i zarządzanie podatkami na kierunku finanse i rachunkowość na Wydziale Zarządzania, Informatyki i Finansów Uniwersytetu Ekonomicznego we Wrocławiu. Ponadto wykorzystano literaturę z zakresu podatków, rachunkowości oraz dydaktyki.

\section{CHARAKTERYSTYKA I ADRESACI SPECJALNOŚCI}

Specjalność doradztwo podatkowe i zarządzanie podatkami przeznaczona jest dla osób, które skupiają swoje zainteresowania zawodowe na podatkach i problematyce skarbowej oraz na analizie decyzyjnej i doradztwie w tym zakresie. Specjalność łączy tematykę podatkową z decyzjami podejmowanymi w różnych obszarach przedsiębiorstwa i koncentruje się na podatkowych konsekwencjach różnych działań i decyzji w przedsiębiorstwach.

Adresatami specjalności są zatem osoby, które chcą nabyć, uzupełnić lub poszerzyć swoją specjalistyczną wiedzę z zakresu rachunkowości i podatków oraz ich wpływu na działalność przedsiębiorstwa. W szczególności dotyczy to analizy podatkowej różnych decyzji, narzędzi zarządzania podatkami, strategii podatkowych, postępowania podatkowego, kontroli podatkowej, wyników przedsiębiorstwa oraz modeli biznesowych. Wskazać można zatem trzy główne obszary zainteresowań zawodowych adresatów specjalności: podatki i problematyka skarbowa, doradztwo i analiza decyzyjna oraz procedury podatkowe $\mathrm{w}$ rachunkowości.

Absolwenci specjalności nabywają praktyczne umiejętności, które dotyczą przede wszystkim prowadzenia podatkowej analizy decyzyjnej, prowadzenia rachunków opłacalności, stosowania strategii podatkowych, identyfikacji i analizy ryzyka podatkowego oraz prowadzenia audytu biznesowego.

Absolwenci specjalności uzyskują kwalifikacje niezbędne w pracy na stanowiskach z obszarów:

- doradztwa podatkowego: jako samodzielny doradca lub konsultant w kancelariach doradców podatkowych i biegłych rewidentów;

- rachunkowości: jako główny księgowy, samodzielny księgowy, specjalista ds. podatkowych i pracownik działu finansowo-księgowego;

- doradztwa biznesowego: jako menedżer, analityk biznesu i konsultant z zakresu podatków. 
Uzyskana wiedza i umiejętności mogą być wykorzystane w szeroko rozumianej działalności konsultingowej i doradczej, jak również w zakładaniu i prowadzeniu własnego biznesu. Istotne jest przy tym to, że zdobyta na specjalności wiedza i umiejętności wykorzystane mogą być podczas prowadzenia działalności przez wszystkie przedsiębiorstwa oraz inne podmioty. Świadczy to o dużej elastyczności specjalności. Ponadto zdobyta wiedza i umiejętności są zgodne nie tylko z polskimi, ale również z unijnymi regulacjami prawa podatkowego i bilansowego.

\section{SPECJALNOŚĆ W PLANIE KSZTAKCENIA NA KIERUNKU FINANSE I RACHUNKOWOŚĆ}

Specjalność doradztwo podatkowe i zarządzanie podatkami kształtuje nie tylko specyfika samego doradztwa i zagadnień podatkowo-ubezpieczeniowych, ale również treści programowe kierunku finanse i rachunkowość oraz całej uczelni. Na Uniwersytecie Ekonomicznym we Wrocławiu program studiów stacjonarnych drugiego stopnia obejmuje łącznie 915 godzin dydaktycznych, z czego 585 godzin stanowią przedmioty kierunkowe, 180 godzin przedmioty specjalnościowe, a 150 godzin - grupa przedmiotów ogólnouczelnianych, humanistycznych i społecznych oraz podstawowych.

Na Wydziale Zarządzania, Informatyki i Finansów, na kierunku finanse i rachunkowość, w roku akademickim 2017/2018 na studiach drugiego stopnia oferowanych jest aż 9 specjalności. Pięć z nich ma profil rachunkowy, a cztery pozostałe dotyczą finansów. W ramach profilu rachunkowego oferowane są specjalności:

- audyt finansowy i podatkowy,

- doradztwo podatkowe i zarządzanie podatkami,

- rachunkowość międzynarodowa,

- rachunkowość i sprawozdawczość podatkowa,

- rachunkowość zarządcza i controlling.

Spośród specjalności o profilu finansowym natomiast studenci mogą wybrać:

- analizę finansową i zarządzanie ryzykiem,

- europejski certyfikat bankowca,

- finanse osobiste,

- menedżera finansowego.

$\mathrm{Na}$ wybraną specjalność studenci zapisują się pod koniec drugiego semestru wraz z równoległym wyborem promotorów, określając tym samym przybliżoną tematykę prac magisterskich. Warto przy tym zauważyć, że na pierwszym roku studiów drugiego stopnia nie jest realizowany żaden przedmiot podatkowy. Chcąc upewnić się o swoich zainteresowaniach obciążeniami publicznoprawnymi, studenci polegać mogą tylko na wiedzy z przedmiotów podatkowych na studiach pierwszego stopnia, jeżeli wcześniej wybrali specjalność rachunkowość i podatki w biznesie lub rachunkowość i auditing. Zagadnienia związane z podatkami oferowane są tylko na tych dwóch specjalnościach. Podczas dwóch pierwszych lat studiów pierwszego stopnia na kierunku finanse i rachunkowość nie jest realizowany przy tym żaden inny przedmiot dotyczący opodatkowania czy obowiązkowych ubezpieczeń przedsiębiorcy. Stanowi to niewątpliwie duże utrudnienie w wyborze specjalności dla studentów. 
Warto również zaznaczyć, że specjalność doradztwo podatkowe i zarządzanie podatkami jest komplementarna do podatkowej specjalności oferowanej na studiach pierwszego stopnia na kierunku finanse i rachunkowość. Dotyczy to specjalności rachunkowość i podatki w biznesie, której celem jest przekazanie wiedzy i umiejętności na temat podatków i innych obciążeń publicznoprawnych. Szczególną uwagę zwraca się w niej na procedury ewidencyjne, rozliczeniowe oraz sprawozdawcze. Jednocześnie przedstawiana jest integracja zagadnień podatkowych z tematyką organizacji rachunkowości, prowadzenia ewidencji księgowej, sporządzania sprawozdań finansowych i innych (Poszwa 2017). Specjalność doradztwo podatkowe i zarządzanie podatkami na studiach drugiego stopnia stanowi natomiast uzupełnienie specjalności na studiach pierwszego stopnia. Skupia się bowiem ona nie na samych procedurach rozliczeniowych, ale na analizie i ocenie konsekwencji podatkowych wynikających, z jednej strony, z przepisów prawa, a z drugiej strony z podejmowanych przez przedsiębiorców decyzji.

Specjalność doradztwo podatkowe i zarządzanie podatkami oferowana będzie studentom po raz pierwszy na kierunku finanse i rachunkowość w semestrze letnim roku akademickiego 2017/2018. Jej program i treści nauczania zostały dostosowane do oczekiwań studentów, zgłaszanych wielokrotnie podczas różnego rodzaju spotkań, z uwzględnieniem rynku pracy.

\section{PRZEDMIOTY SPECJALNOŚCI I TREŚCI NAUCZANIA}

W ramach specjalności oferowanych jest 6 przedmiotów (obligatoryjnych), które realizowane są na drugim roku studiów. Łączny wymiar godzin tych przedmiotów wynosi odpowiednio 180 godzin zajęć na studiach stacjonarnych oraz 96 godzin na studiach niestacjonarnych. Każdy z tych przedmiotów realizowany jest w formie wykładów i ćwiczeń w jednakowych proporcjach - po 15 godzin wykładów i ćwiczeń na studiach stacjonarnych oraz po 8 godzin na niestacjonarnych.

Cztery przedmioty specjalnościowe występują w $\mathrm{V}$ semestrze, a dwa pozostałe w semestrze następnym. W pierwszym bloku studenci zobowiązani są zaliczyć następujące przedmioty:

- analizy i decyzje podatkowe,

- podatki w sprawozdawczości finansowej,

- postępowanie i kontrolę podatkową,

- zarządzanie wynikami.

W następnym semestrze realizowane są natomiast dwa kolejne przedmioty specjalnościowe:

- audyt biznesowy,

- opodatkowanie międzynarodowe.

W ramach przedmiotu analizy i decyzje podatkowe prezentowane są podatkowe aspekty w różnych obszarach decyzyjnych. Analizie poddaje się, z jednej strony, skutki regulacji podatkowych, jakie wywierają one na przedsiębiorstwo i jego działalność. Z drugiej strony badane są też konsekwencje podatkowe, które wynikają z podejmowanych różnorodnych decyzji biznesowych. Jednocześnie $w$ ramach tego przedmiotu prezentowane są rodzaje decyzji podatkowych oraz same instrumenty optymalizacji ciężaru podatkowego w wielu obszarach otoczenia przedsiębiorstwa - zarówno wewnętrznego, jak i zewnętrznego. 
Analizie podatkowej podlegają między innymi wybór miejsca siedziby, decyzje związane ze sposobem finansowania działalności, problem niedostatecznej kapitalizacji, cen transferowych. Przedmiot analizy i decyzje podatkowe obejmuje również analizę ryzyka podatkowego i procedurę wyboru odpowiedniej dla przedsiębiorcy strategii podatkowej. Najważniejszym efektem przedmiotu powinna być umiejętność przewidywania i oceny wpływu podatków na decyzje przedsiębiorstwa oraz umiejętność analizy ryzyka podatkowego i wyboru korzystnego sposobu postępowania.

Przedmiot podatki w sprawozdawczości finansowej dotyczy przede wszystkim ukazania odmiennego postrzegania przychodów i kosztów przez prawo bilansowe i podatkowe; przedstawia również zagadnienie podatkowe w sprawozdawczości oraz w polityce rachunkowości. Analizie podlega też rachunek odroczonego podatku dochodowego $w$ świetle regulacji wynikających z Krajowego standardu rachunkowości nr 2 oraz Międzynarodowego standardu rachunkowości nr 12. Prezentowane są również skutki bilansowe wynikające ze stosowania odroczonego podatku dochodowego. Ponadto w ramach przedmiotu podatki w sprawozdawczości przeprowadzana jest analiza efektywności opodatkowania wyniku podatnika. Efektem wykładów i ćwiczeń powinna być zatem umiejętność ujmowania podatków odroczonych w sprawozdaniu finansowym oraz przewidywania skutków odmiennego podejścia prawa podatkowego i bilansowego do przychodów i kosztów.

Równolegle do wymienionych kursów realizowany jest również przedmiot specjalnościowy postępowanie i kontrola podatkowa. Ma on za zadanie przede wszystkich przedstawić zasady funkcjonowania krajowej administracji skarbowej. W ramach tego przedmiotu prezentowane są procedury kontroli i postępowania podatkowego. Studenci zaznajamiają się z regulacjami w zakresie przestępstw i wykroczeń podatkowych oraz informowani są o odpowiedzialności za te czyny. Po wykładach i ćwiczeniach z tego przedmiotu student powinien zatem umieć wykorzystać wiedzę z procedur postępowania i kontroli podatkowej w przedsiębiorstwie.

Ostatni przedmiot specjalnościowy w trzecim semestrze to zarządzanie wynikami. Przedmiot ten zapoznaje studentów z decyzyjnymi rachunkami wyników i koncepcją zarządzania wynikami poprzez kształtowanie przychodów i kosztów. Prezentowane jest zarówno podejście krótkoterminowe, jak i długoterminowe. W ramach przedmiotu zarządzanie wynikami przedstawiane są narzędzia zarządzania przychodami i kosztami w różnych obszarach działalności. Jednocześnie prezentowane są zasady i sposoby projektowania rachunku wyników na potrzeby zarządzania. Tym samym studenci poznają budowę systemu informacyjnego przedsiębiorstwa dostarczającego danych o kosztach i wynikach oraz determinanty zarządzania wynikiem w różnych obszarach działalności. Efektem tych zajęć powinna być umiejętność sporządzania, kształtowania i analizy krótkoterminowego oraz długoterminowego rachunku wyników. Student powinien również umieć zbadać rentowność oraz wpływ czynników ją kształtujących.

W kolejnym (ostatnim) semestrze studiów prowadzony jest przedmiot opodatkowanie międzynarodowe, w którym przedstawiane są regulacje międzynarodowe w obszarze podatków. Zwracana jest przy tym uwaga na harmonizację podatków zarówno bezpośrednich, jak i pośrednich. W ramach tego przedmiotu omawiany jest jednocześnie temat rezydencji podatkowej oraz problem podwójnego opodatkowania. Prezentowane są również 
zagadnienia dotyczące opodatkowania dochodów z zagranicy oraz międzynarodowe aspekty opodatkowania dochodów spółek kapitałowych i ich wspólników, a także planowania podatkowego w holdingach międzynarodowych. Podstawowymi efektami zajęć z opodatkowania międzynarodowego są umiejętność stosowania procedury unikania podwójnego opodatkowania oraz umiejętność stosowania procedur opodatkowania dochodów transgranicznych.

Równolegle w ostatnim semestrze studiów w ramach specjalności prowadzony jest przedmiot audyt biznesowy. Ma on na celu, między innymi, wskazać obszary audytu w przedsiębiorstwie oraz zapoznać studentów z metodami oceny modelu biznesowego przedsiębiorstwa. Prezentowane są przede wszystkim metody analizy finansowej, pomiar dokonań oraz analiza otoczenia w audycie biznesu przedsiębiorstwa. Przedstawione są również analiza i ocena modelu biznesowego przedsiębiorstwa w tworzeniu wartości, a także procedura projektowania i oceny nowego modelu biznesowego. Najważniejszymi umiejętnościami zdobytymi w ramach przedmiotu audyt biznesu są umiejętność dostosowania metody analizy finansowej do potrzeb audytu biznesu przedsiębiorstwa oraz umiejętność wykorzystania narzędzia oceny i projektowania modelu biznesowego.

\section{METODY DYDAKTYCZNE NA SPECJALNOŚCI PODATKOWO-DORADCZEJ}

Dobór odpowiednich metod dydaktycznych może okazać się kluczowy dla osiągnięcia zakładanych efektów specjalności. Przy ich doborze należy wziąć pod uwagę przed wszystkim specyfikę specjalności, treści programowe poszczególnych przedmiotów oraz percepcję studentów studiów drugiego stopnia, którzy z zdecydowanej większości (ok. 85\%) posiadają już doświadczenie zawodowe zgodne ze studiowanym kierunkiem studiów (Klinowski 2016).

Specjalność doradztwo podatkowe i zarządzanie podatkami bazuje w dużym stopniu na przepisach prawa. Wymusza to na prowadzących zajęcia konieczność nieustającego monitorowania zmian $w$ regulacjach i przyswajania nowych rozwiązań. W kształceniu studentów istotne jest przy tym to, aby nie tylko przekazać treść przepisów lub ich zmian, ale także umiejętność stosowania tychże przepisów. Zasadne jest zatem stosowanie metody analizy przypadków. Dodatkowo należałoby wykształcić u studentów potrzebę samodzielnego doszkalania się oraz umiejętność pozyskiwania nowych informacji. Jest to niezbędne do utrzymania się na rynku pracy w obszarze doradczym. Ponadto ze względu na charakter specjalności dużo uwagi należy poświęcić na rozwijanie kompetencji analitycznych studentów. Osiągnąć to można na przykład poprzez rozwiązywanie wybranych problemów z praktyki gospodarczej.

Warto przy tym zaznaczyć, że w procesie dydaktycznym równie istotna jest właściwa komunikacja między wykładowcą a prowadzącym ćwiczenia. Dbałość o korelację między treściami wykładu i zajęciami ćwiczeniowymi może okazać się nieoceniona w osiągnięciu celów przedmiotów i w konsekwencji celów samej specjalności.

Studenci oczekują ponadto od prowadzących zajęcia odpowiednich metod dydaktycznych, które umożliwią im zrozumienie często skomplikowanych mechanizmów rozliczeniowych i zagadnień z zakresu podatków i doradztwa. Według studentów najbardziej odpowiednią formą przekazywania treści na wykładach podatkowo-doradczych jest studium przypadku lub 
wykład z prezentacją multimedialną. Natomiast zajęcia ćwiczeniowe, zdaniem studentów, powinny być realizowane poprzez rozwiązywanie zadań na tablicy lub $\mathrm{w}$ formie studium przypadku. Warto jeszcze dodać, że z elementów najlepiej weryfikujących wiedzę i umiejętności studenci najczęściej wskazują zadania do rozwiązania, co jest zbieżne z ich oczekiwaniami wobec formy prowadzenia ćwiczeń (Klinowski 2017).

Przedstawione elementy procesu dydaktycznego stanowią niewątpliwie kluczowe czynniki w kreowaniu specjalności dla osiągnięcia jej celu głównego. Nieustające doskonalenie procesu dydaktycznego decyduje bowiem o przydatności i atrakcyjności oferty kształcenia dla studentów.

\section{PODSUMOWANIE}

W niniejszym opracowaniu zaprezentowano i przeanalizowano koncepcję podatkowej specjalności na studiach drugiego stopnia na kierunku finanse i rachunkowość Wydziału Zarządzania, Informatyki i Finansów na Uniwersytecie Ekonomicznym we Wrocławiu. Specjalność doradztwo podatkowe i zarządzanie podatkami zorientowana jest na specjalistyczną wiedzę i umiejętności z zakresu analizy podatkowej, narzędzi zarządzania podatkami, a także postępowania i kontroli podatkowej oraz z zakresu analizy decyzyjnej i modeli biznesu. Charakterystyczne dla prezentowanej specjalności jest uzyskanie praktycznych umiejętności niezbędnych w każdej działalności. Potencjalnie stwarza to szerokie możliwości samorozwoju w ramach własnej działalności gospodarczej lub zatrudnienia na samodzielnych stanowiskach w przedsiębiorstwach, kancelariach doradców podatkowych i biegłych rewidentów, w biurach rachunkowych, podmiotach konsultingowych, a także w administracji podatkowej. Jednocześnie metody nauczania poszczególnych przedmiotów specjalnościowych zostały tak dobrane, aby, z jednej strony, były zbieżne z oczekiwaniami studentów, a z drugiej strony, aby umożliwiały właściwe przekazanie treści kształcenia. Wszystko to sprawia, że specjalność doradztwo podatkowe i zarządzanie podatkami może stać się atrakcyjną ofertą kształcenia dla studentów studiów drugiego stopnia. Przypuszczenie to potwierdzają wyniki ankiet przeprowadzonych wśród studentów części grup na studiach drugiego stopnia na kierunku finanse i rachunkowość, którym oferowana będzie opisywana specjalność podatkowa. Ponad 1/3 ankietowanych osób była zdecydowana wybrać lub poważnie rozważała wybór specjalności doradztwo podatkowe i zarządzanie podatkami. Oznacza to, że ta oferowana po raz pierwszy w roku akademickim 2017/2018 specjalność podatkowa ma duże szanse na uruchomienie.

\section{PIŚMIENNICTWO}

Biernacki M. 2016. Oczekiwania zawodowe studentów rachunkowości z pokolenia Z. Folia Pomer. Univ. Technol. Stetin., Ser. Oeconomica 327(83)2, 15-26.

Klinowski M. 2016. Miejsce przedmiotów dotyczących podatków na studiach ekonomicznych i ich postrzeganie przez studentów. Folia Pomer. Univ. Technol. Stetin., Ser. Oeconomica 327(83)2, 77-88.

Klinowski M. 2017. Metodyka prowadzenia zajęć z rachunkowości podatkowej na uczelniach ekonomicznych. Folia Pomer. Univ. Technol. Stetin., Ser. Oeconomica 335(87)2, 113-122. 
Kuzior A., Rówińska M. 2016. Specjalności z zakresu rachunkowości - przegląd oferty dydaktycznej uczelni publicznych. Folia Pomer. Univ. Technol. Stetin., Ser. Oeconomica 327(83)2, 137-148.

Poszwa M., 2017. Koncepcja specjalności z zakresu podatków na studiach pierwszego stopnia na kierunku finanse I rachunkowość. Folia Pomer. Univ. Technol. Stetin., Ser. Oeconomica 327(87)2, 225-232.

Streszczenie. Celem niniejszego opracowania jest prezentacja i analiza koncepcji oraz treści nauczania na specjalności doradztwo podatkowe i zarządzanie podatkami. Jest ona oferowana na studiach drugiego stopnia na kierunku finanse i rachunkowość Wydziału Zarządzania, Informatyki i Finansów na Uniwersytecie Ekonomicznym we Wrocławiu. Specjalność zorientowana jest na specjalistyczną wiedzę i umiejętności z zakresu analizy podatkowej, narzędzi zarządzania podatkami, a także z zakresu postępowania i kontroli podatkowej oraz analizy decyzyjnej i modeli biznesu. Dobór odpowiednich metod dydaktycznych może okazać się kluczowy dla osiągnięcia zakładanych efektów specjalności. Przy ich doborze należy wziąć pod uwagę przed wszystkim specyfikę specjalności, treści programowe poszczególnych przedmiotów oraz percepcję studentów. Nieustające doskonalenie procesu dydaktycznego decyduje bowiem o przydatności i atrakcyjności oferty kształcenia dla studentów. 